actual documentation and/or publication of their work. Thus, the extraordinary evolution and influence of history upon contemporary science and practice may not be fully appreciated and could potentially be lost to future generations of workplace health and safety researchers and practitioners.

Methods Join us as we explore this phenomenon and engage one another in identifying key resources and platforms for the selection, archival, and preservation of the essential historical resources connecting our past to the present day. In this workshop, we will reflect on the merits of establishing a centralised database for historical documents, share choices in personal archival methodology and technology, fully explore The History of Prevention of Occupational and Environmental Diseases web archive project, and provide practical hand-on experience in the archival of one's own content. In preparation, workshop participants are urged to bring three pieces of informational content (i.e., paper documents or electronic publications) to contribute to the archive.

Results This workshop will highlight the significance of historical preservation and impart methodology, technology, and best practices for the archival of historical documents. Through practical experience in contributing content to a centralised platform, participants will learn the steps necessary to establish one's own strategy for archival.

Conclusion Our goal is to reintroduce historic research into the occupational safety and health community - saving valuable time and resources spent to rediscover historical significance. A concerted effort to preserve and share accrued knowledge will afford current and future generations with the opportunity to more fully explore historic 'windows of influence' and lessons learned, providing foundational elements upon which to discover future avenues for the reduction of harmful occupational exposures and improved worker protection across the U.S. and around the world.

\section{HISTORICAL PERSPECTIVES ON OCCUPATIONAL HEALTH IN IRELAND}

${ }^{1}$ Paul D Blanc*, ${ }^{2}$ Alfredo Menendez-Navarro, ${ }^{3} \mathrm{~J}$ Hayes, ${ }^{4} \mathrm{AE}$ Evans, ${ }^{5} \mathrm{~K}$ Addley, ${ }^{6} \mathrm{JM}$ Malone. ${ }^{1}$ University of California San Francisco San Francisco, California, USA; ${ }^{2}$ Univesidad de Granada, Granada, Spain; ${ }^{3}$ Department of Respiratory Medicine, RCSI Hospital Group Ireland; ${ }^{4}$ The Centre for Public Health, The Queen's University of Belfast; ${ }^{5}$ Faculty of Occupational Medicine, Royal College of Physicians of Ireland, Dublin, Ireland; ${ }^{6}$ The Faculty of Occupational Medicine Royal College of Physicians of Ireland

\subsection{6/oemed-2018-ICOHabstracts.530}

Aim of special session This session will address the Irish perspective on the history of occupational disease.

\section{8a THE LONG HISTORY OF AGRICULTURE AND OCCUPATIONAL DISEASE IN IRELAND}

J Hayes. Department of Respiratory Medicine, RCSI Hospital Group Ireland

\subsection{6/oemed-2018-ICOHabstracts.531}

Since man arrived to Ireland agriculture has been integral to the political cultural and economic development of our society. Indeed our principal mythology involves a row over a prize bull. Early settlers probably came from northern Spain or southern France some 10,000 years ago and were hunter gatherers. Early evidence shows increased deforestation with cereal growing mainly oats and barley. Although some settlements developed in proximity to Christian monasteries, urbanisation came with the Vikings in medieval times. Significant geopolitical change did not occur until the 18th century with the collapse of the Celtic society. With the plantations came the development of modern agriculture in Ireland. Industrialisation, with the exception of the northeast, did not occur in Ireland. Agricultural developments saw flax in Ulster, tillage in Leinster and dairying in Munster. However whether freehold or tenant $50 \%$ of holdings in the early 1800 s were between one and five acres. With increasing need to sell product tenant, farmers became dependent on the potato for sustenance and on the 'lumper' in particular. By the 1840 s, the population had increased to 8 million. The famine of the 1840 s due to failure of the potato crop resulted in significant death and emigration. In the twentieth century holdings increased in size with the focus on dairy and beef. Agricultural related industries such as brewing, sugar production and flour production continued. The utilisation of peat for the development of turfrelated industries occurred in the twentieth century. Currently, the emphasis on the whole island remains on dairy and beef production. Improvement in regulation through the European Union has resulted in fewer farm accidents, reduction in respiratory and dermatological conditions The agrifood sector accounts for $10 \%$ of employment today. Holding remains small and part time farming is common.

\section{8b FLAX AND LINEN IN THE HISTORY OF IRISH INDUSTRIAL HEALTH}

AE Evans. The Centre for Public Health, The Queen's University of Belfast

10.1136/oemed-2018-ICOHabstracts.532

Flax was once grown in every county of Ireland, when the production of linen was an entirely cottage industry. After the Williamite war of 1691 immigration to Ireland was encouraged and many who came were Huguenots from France. Notably Louis Crommellin came to Lisburn, in County Down, to establish a colony of Huguenot linen weavers. Just how much their arrival contributed to innovation is arguable but they enriched the range of linen idiom. Linen manufacture came to be concentrated in north-west Ulster. Ramazzini, in 1705, had noted respiratory problems associated with 'a foul mischievous powder' entering the lungs of flax hacklers, but it was not until production was mechanised in the 19th Century that it became a serious problem. In 1831 Thackrah described similar cases in Leeds; by 1860 Greenhow had employed the term 'Byssinosis' (from the Greek 'bussinos' - of linen) in an official document and recorded that the condition was exacerbated on Mondays, ie 'Monday Fever.' In 1856, Malcolm in Belfast, demonstrated that the condition was related to the initial, dustier phases of linen manufacture. Another Ulster doctor, Charles Nicholas Delacherois Purdon (who had Huguenot forebears), in the 1870s described diseases associated with linen manufacture: '...one of the most injurious, and in certain branches very fatal, is the effect induced by the inhaling of flax dust, called by the workers 'Pouce,' (from the French: 'poussif' - wheezy) which is produced, when the fibre is cleansed by machinery.' Those employed as 'doffers' (from the French: 'démonteurs' dismantlers) who removed the spindles did not suffer from Pouce because they were exposed to heat and vapour rather than dust which rendered them more susceptible to bronchial 
attacks '(Mill Fever).' Thanks to John Pemberton's (and others') research at The Queen's University of Belfast, Flax Byssinosis became a Prescribed Industrial Disease in 1965.

\section{C SHIPBUILDING IN BELFAST IN THE EARLY TWENTIETH CENTURY: THE TITANIC ERA AND ASSOCIATED HEALTH AND SAFETY MATTERS}

K Addley. Faculty of Occupational Medicine, Royal College of Physicians of Ireland, Dublin, Ireland

\subsection{6/oemed-2018-ICOHabstracts.533}

In the 1830's, factory-based linen production had made Belfast the most important industrial town in Ireland and the addition of shipbuilding in the 1880 's completed its transformation to a major manufacturing city. There was access to a ready pool of unskilled local labour with a robust work ethic and shipbuilding was one of the city's main employers giving it both wealth and prestige. It was a vibrant, expanding industry whose later decline greatly affected Belfast and its people. The period between 1880 - 1914 was the golden age of Belfast shipbuilding, with massive growth in the industry specialising in passenger liners, cargo-passenger ships and large ocean-going cargo vessels. During this time, Belfast was producing up to $10 \%$ of the British merchant shipping output. Harland and Wolff is the best known of the Belfast shipbuilders employing in the period 1900-20, 20000 workers. Between 1914 - 1918 saw the beginning of a decline of shipbuilding in Belfast. Shipyard work was heavy and hazardous with many physical hazards including falls, noise and vibration. Asbestos was frequently used leading to asbestosis, pleural plaques, and pleural mesothelioma. There were safety and health shortcomings consistent with the time and a health legacy in regard to asbestos-related lung disease, mesothelioma, occupational deafness and vibration white finger. There was recognition of the potential that materials being used may have long latency health risk, avoiding complacency, also that learning from mistakes and improved engineering design and safety equipment on board vessels can markedly improve worker safety and health and save lives. The workers of the Belfast shipyard would perhaps be proud to see their story being told today as part of the regeneration of Belfast with the city moving forward after many years of conflict and decline.

\section{8d OCCUPATIONAL HEALTH IN IRELAND AS A PROFESSION - THE LAST 50 YEARS. WHILE RAMAZINNI IS THE GRANDFATHER OF OCCUPATIONAL HEALTH, IS THERE AN IRISH PHYSICIAN WHO IS THE GREAT GRANDFATHER OF OCCUPATIONAL HEALTH?}

JM Malone. The Faculty of Occupational Medicine Royal College of Physicians of Ireland

\subsection{6/oemed-2018-ICOHabstracts.534}

The Faculty of Occupational Medicine, Royal College of Physicians of Ireland (RCPI) was founded in 1976. Its objective was to advance the science and practice of occupational medicine and to promote education, study and research in the specialty. Its core membership has all-Ireland representation, stemming from the College's Royal Charters in the seventeenth century. The Faculty has been an integral part of RCPI since its inception. The Faculty was involved in occupational medicine being recognised as both an Irish and
European Medical Specialty. It developed the Licentiate and Membership Examinations which became sought after qualifications at home and abroad. It has held annual examinations in Ireland since 1983 and holds annual overseas examinations in Malaysia since 1995 and more recently in the $\mathrm{Al}$ Ain. The Faculty initiated and maintains a comprehensive training scheme for its specialist doctors in training. This paper gives a chronological account of the activities of the Faculty, from the mid1970's up to current times. It is based on the archive records of the Faculty, including the minutes of the Board meetings of the Faculty and the College (RCPI). It covers that period of change that affected many disciplines involved in occupational health i.e. nurses, hygienists, toxicologists, safety officers, psychologists and others, as well as the changes that the factory doctor underwent as he/ she became a 21 st century occupational physician. The role of the Faculty is to maintain integrity and professional competence of doctors engaged in occupational medicine. It operates the professional competence scheme on behalf of the Medical Council for specialist occupational health physicians.

\section{OCCUPATIONAL HEALTH AND SAFETY PERSPECTIVES OF LOUISIANA FIRST RESPONDERS INVOLVED IN THE 2010 DEEPWATER HORIZON OIL SPILL}

${ }^{1} J o h n a t h a n$ Z Pangborn*, ${ }^{1}$ Kevin J Moore, ${ }^{1}$ Katerina M Santiago, ${ }^{2}$ Edward J Trapido, ${ }^{3}$ Wilma A Subra, ${ }^{4}$ Lora E Fleming, ${ }^{1}$ Alberto I Caban-Martinez. ${ }^{1}$ University of Miami, Miller School of Medicine, Department of Public Health Sciences, Miami FL, USA; ${ }^{2}$ Louisiana State University, School of Public Health, Department of Epidemiology, New Orleans LA, USA; ${ }^{3}$ Subra Company, Louisiana Environmental Action Network, Lower Mississippi Riverkeeper, New Iberia LA, USA; ${ }^{4}$ European Centre for Environment and Human Health, University of Exeter Medical School, Truro, Cornwall, UK

\subsection{6/oemed-2018-ICOHabstracts.535}

Introduction The 2010 Deepwater Horizon oil spill is considered the largest accidental marine oil spill in United States history. The oil spill had severe environmental impacts on the United States Gulf coastline as well as far-reaching effects on the health and safety of first responders. Despite national significance of the oil spill, there is limited information documenting the long-term health and safety experience of this workforce. This study examines the occupational health and safety perspectives of first responders involved in the 2010 Deepwater Horizon oil spill.

Methods Six focus group sessions (8-10 participants each) were conducted in May 2017. Firefighters were consented and invited to complete a self-administered questionnaire, followed by a $60 \mathrm{~min}$ semi-structured focus group session assessing perceptions of safety and health conditions related to the oil spill event. Focus group audio files were transcribed verbatim and analysed using a general inductive approach to identify emergent themes.

Result Study participants $(\mathrm{n}=50)$ were mostly male $(98.0 \%)$, non-Hispanic $(95.3 \%)$, white $(98.0 \%)$, with a mean age of 40.6 years (standard deviation $[\mathrm{SD}]=9.8$ ), and mean job tenure of 15.3 years $(\mathrm{SD}=8.2)$. Among respondents, $56.3 \%$ of participants reported direct contact with oil, $36.7 \%$ visited a doctor after the oil spill, and $18.8 \%$ reported feeling chronic ( $\geq 3$ months) musculoskeletal pain following recovery efforts. Major themes that emerged included concerns regarding personnel decontamination procedures, heat-related illnesses, ocular disorders, fear of cross-contamination, and unknown long- 